\title{
Osmotic Response of Cortisol Treated Fresh Water Fish - Oreochromis mossambicus Exposed to Pesticides
}

\author{
Jensy Roshan $\mathbf{F}^{1}$, Dr. Anila George ${ }^{2}$ \\ ${ }^{1}$ Assistant Professor, Dept. of Zoology, St. Johns College, Anchal, Kollam, Kerala, India \\ ${ }^{2}$ Assistant Professor, Dept. of Environmental Science, St. Johns College Anchal, Kollam, Kerala, India
}

\begin{abstract}
The activity of osmotic organs is affected by the changes in the physico-chemical nature of the medium, which is altered by the extensive use of pesticides that affect osmotic balance. The present study is focused on the osmotic response of cortisol treated fresh water fish Oreochromis mossambicus, exposed to pesticides like lindane, nuvacrom and sevin. Membrane protein concentration of gill filaments shows mark increase when exposed to sub lethal concentration of pesticides due to histopathological alteration induced by pesticides. The $\mathrm{Na}^{+} \mathrm{K}^{+}$ATPase activity in gill filaments is enhanced by pesticide exposure. Pesticides induce stress which alters the ionic composition of external and internal milieu of fish. To recompense the change the fish responds by stimulating the osmotic organs like gills. It is reflected in the elevated rate of activity of branchial $\mathrm{Na}^{+} \mathrm{K}^{+} \mathrm{ATPase}$. Cortisol treatment increases the membrane protein concentration and $\mathrm{Na}^{+} \mathrm{K}^{+}$ATPase activity; but the hike is not as great as that caused by pesticides. In vivo administration of cortisol to fishes, exposed to sub lethal concentration of pesticides, also stimulates the $\mathrm{Na}^{+} \mathrm{K}^{+} \mathrm{ATPase}$ activity. In this case it is very noteworthy that the $\mathrm{Na}^{+} \mathrm{K}^{+} \mathrm{ATPase}$ activity is brought to the normal level. The stress induced by pesticides is compensated by the hormone cortisol as evidenced in the attainment of normal activity of branchial $\mathrm{Na}^{+} \mathrm{K}^{+}$ATPase in hormone treated fishes exposed to pesticides. Pesticides polluting our water resources endanger the wonder-provoking biodiversity. This paper invites the attention of the public and the authorities concerned to expedite immediately legislative measures and effect public conscientisation against the indiscriminate use of pesticides.
\end{abstract}

Keywords: Osmotic balance, Cortisol, $\mathrm{Na}^{+} \mathrm{K}^{+}$ATPase, Pesticides, Lindane, Nuvacron, Sevin

\section{Introduction}

Animals occupy diverse osmotic environment, in which the availability of salt and water varies. Water is indispensable for life. For the proper functioning of cells, certain healthy concentration of many dissolved substances, especially sodium and potassium should be maintained. $\mathrm{Na}^{+} \mathrm{K}^{+}$ATPase is associated with osmoregulation in fish because it indirectly energizes the branchial excretion of NaCl.[4], [11],[31]

The aquatic medium in which the fish lives facilitate the free flow of water an ions in and out the body through the function of osmoregulatory organs. Activities of these organs are affected by any change in the physico-chemical nature of the medium, which is altered by extensive use of pesticides. This in turn alters the osmotic balance [21]. The regulation of $\mathrm{Na}^{+} \mathrm{K}^{+}$ATPase activity is shown to be under endocrine control [24]. Cortisol therapy stimulates $\mathrm{Na}^{+} \mathrm{K}^{+}$ATPase activity in a variety of fish species and also increases tolerance to high salinities [20],[25], [29]. Cortisol plays a central osmoregulatory role during acclimation to both hyper and hyposaline environments in teleosts [3], [24],[26]. The activity of $\mathrm{Na}^{+} \mathrm{K}^{+}$ATPase in fish gill may be a useful nonspecific biomarker as it is easily quantified and affected by a variety of pollutants [9],[17],[27]. The present study is focused on the osmotic response of cortisol treated fresh water fish, Oreochromis mossambicus, exposed to pesticides like lindane, nuvacron and sevin.

\section{Materials and Method}

Healthy specimens of Oreochromus mossambicus were collected from Vattakayal, Kollam district. Fishes were acclimatized for 2 weeks in large storage tanks, supplied with fresh well water and were fed ad libitum with commercial fish feed. Fish ranging from 10-12 cm length and 18-20 g in body weight were selected for the study. They were starved for 24 hours before experimental analysis. Toxicants selected for the present study were lindane (organochlorine), sevin (carbonate), and nuvacron (organophosphorous). The sub lethal concentration value were calculated $(0.5 \mathrm{ppm}$ for lindane, $0.2 \mathrm{ppm}$ for sevin and 0.2ppm for nuvacron), for the present study.

\subsection{Experimental procedure}

Two sets of experiments were conducted. The first set is treated with different pesticides to study the physiological effect of pesticides. The second set is subjected to hormonal and pesticidal treatment to study the osmoregulatory role of hormone.

Set I: Four groups of 25 fishes each were kept in identical glass tanks containing dechlorinated tap water. Fishes of group 1, serve as a control and are not exposed to pesticides. Fishes of group 2, 3, and 4 were exposed to sub lethal concentration of lindane, nuvacron and sevin respectively. All the fishes were killed after 24 hours of exposure to the respective pesticides. Care was taken to ensure that the pesticide concentrations were maintained at their respective levels and oxygen availability does not act as a limiting factor. Fishes were starved for 24 hours prior to biochemical analysis. 


\section{International Journal of Science and Research (IJSR) \\ ISSN (Online): 2319-7064 \\ Index Copernicus Value (2013): 6.14 | Impact Factor (2014): 5.611}

Set II: Five groups of experiments were conducted. Each group contains 25 fishes and each group was transferred to identical glass tanks. The first group of fishes received no hormonal injection and was not exposed to any pesticides serve as a control. The fishes of group 2 were given intraperitoneal hydrocortisone injection and were not exposed to any pesticides. Group 3, 4 and 5 fishes were given intraperitoneal hydrocortisone injection and exposed to sub lethal concentration of lindane, nuvacron and sevin respectively. The hormone hydrocortisone, diluted in fish saline was used for administration.

Estimation of membrane protein: Membrane protein of gill filaments was estimated spectrophotometrically according to the method of Lowry et al [22], using bovine serum albumin as standard. The amount of Protein was expressed as $\mathrm{mg} / \mathrm{ml}$.

Assay of enzyme activity: $\mathrm{Na}^{+} \mathrm{K}^{+}$ATPase activity was measured from the amount of inorganic phosphate (Pi) released, essentially according to the procedure of Bonting [28]. Data were collected from all the animals of each test and each set. Results are reported as mean \pm SD.

\section{Result}

- Effect of pesticides: Exposure of Oreochromis mossambicus to sub lethal concentrations of lindane, nuvacron and sevin increases the membrane protein content of gills and its osmoregulatory enzyme $\mathrm{Na}^{+} \mathrm{K}^{+} \mathrm{ATPase}$ activity. This is clearly shown in the table I and III and fig. I and III.

- Effect of hormone hydrocortisone: Membrane protein content and $\mathrm{Na}^{+} \mathrm{K}^{+}$ATPase activity in the gill filaments is enhanced by hydrocortisone treatment. The activity of the enzyme was not as high as that found in the fishes that were exposed to pesticides. $\mathrm{Na}^{+} \mathrm{K}^{+}$ATPase activity was almost close to that found in control group (table II and IV, fig. II and IV).

- Effect of hormone hydrocortisone and pesticides: Protein content was enhanced in fishes that were treated with pesticide and hydrocortisone. The activity of $\mathrm{Na}^{+} \mathrm{K}^{+}$ATPase was brought close to the level of activity as that of normal untreated fishse seen in control group (table II, IV and fig II, IV).

From the above results we confirm that cortisol has nullified the effect of pesticides on $\mathrm{Na}^{+} \mathrm{K}^{+}$ATPase as osmoregulatory enzyme found in the gill of fish.

Table 1: Membrane protein concentration in the gill of Oreochromis mossambicus exposed to pesticides (each value represents mean \pm SD of 25 fishes).

\begin{tabular}{|c|c|c|c|}
\hline Control mg/ml & Lindane & Nuvacron & Sevin \\
\hline $7.18 \pm 1.05$ & $7.28 \pm .70$ & $8.74 \pm 0.61$ & $8.15 \pm 0.97$ \\
\hline
\end{tabular}

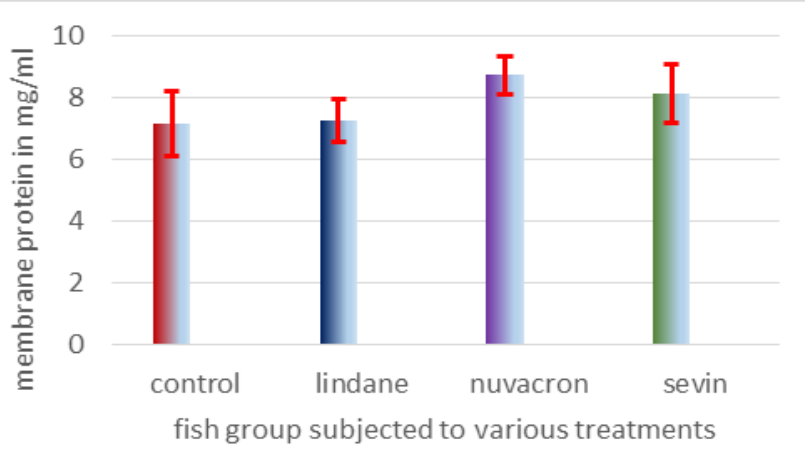

Figure 1: Membrane protein concentration in the gill of Oreochromis mossambicus exposed to pesticides

Table 2: Membrane protein concentration in the gill of Oreochromis mossambicus treated with HC and exposed to pesticides (each value represents mean \pm SD of 25 fishes).

\begin{tabular}{|c|c|c|c|c|}
\hline $\begin{array}{c}\text { Control } \\
\mathrm{mg} / \mathrm{ml}\end{array}$ & HC & $\begin{array}{c}\text { Lindane }+ \\
\text { HC }\end{array}$ & $\begin{array}{c}\text { Nuvacron }+ \\
\text { HC }\end{array}$ & Sevin + HC \\
\hline $7.18 \pm 1.05$ & $9.33 \pm 2.52$ & $8.45 \pm 0.76$ & $\begin{array}{c}10.45 \pm \\
1.52\end{array}$ & $8.62 \pm 0.94$ \\
\hline
\end{tabular}

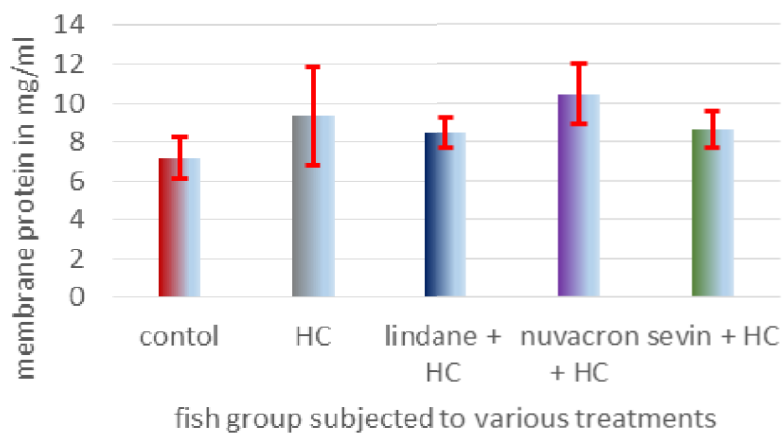

Figure 2: Membrane protein concentration in the gill of Oreochromis mossambicus treated with $\mathrm{HC}$ and exposed to pesticides

Table 3: $\mathrm{Na}^{+} \mathrm{K}^{+}$ATPase activity in the gill of Oreochromis mossambicus exposed to pesticides (each value represents mean \pm SD of 25 fishes).

\begin{tabular}{|l|c|c|c|}
\hline Control mg/ml & Lindane & Nuvacron & Sevin \\
\hline $127.18 \pm 2.08$ & $187.54 \pm 3.59$ & $181.44 \pm 2.76$ & $175.45 \pm 2.39$ \\
\hline
\end{tabular}

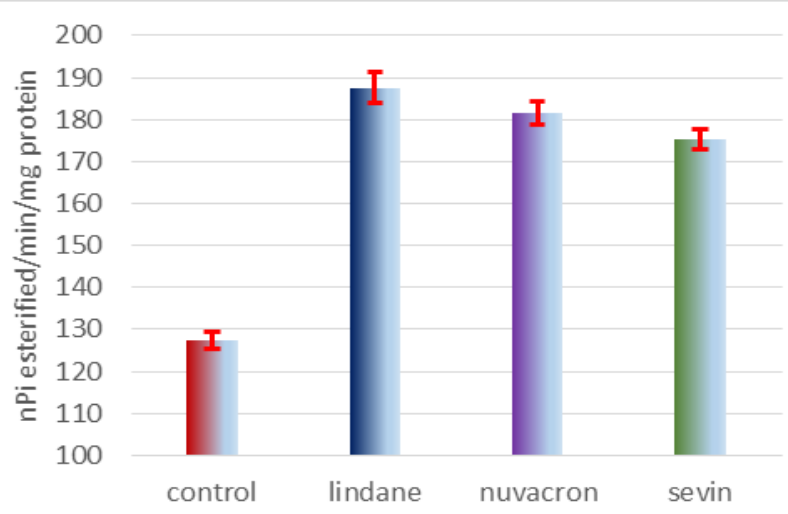

fish group subjected to various treatments

Figure 3: $\mathrm{Na}^{+} \mathrm{K}^{+}$ATPase activity in the gill of Oreochromis mossambicus exposed to pesticides 


\section{International Journal of Science and Research (IJSR) \\ ISSN (Online): 2319-7064 \\ Index Copernicus Value (2013): 6.14 | Impact Factor (2014): 5.611}

Table 4: $\mathrm{Na}^{+} \mathrm{K}^{+}$ATPase activity in the gill of Oreochromis mossambicus treated with $\mathrm{HC}$ and exposed to pesticides (each value represents mean \pm SD of 25 fishes).

\begin{tabular}{|c|c|c|c|c|}
\hline $\begin{array}{c}\text { Control } \\
\mathrm{mg} / \mathrm{ml}\end{array}$ & HC & $\begin{array}{c}\text { Lindane }+ \\
\text { HC }\end{array}$ & $\begin{array}{c}\text { Nuvacron } \\
+ \text { HC }\end{array}$ & Sevin + HC \\
\hline $\begin{array}{c}127.48 \pm \\
2.08\end{array}$ & $\begin{array}{c}132.895 \pm \\
2.57\end{array}$ & $\begin{array}{c}130.08 \pm \\
1.81\end{array}$ & $\begin{array}{c}129.11 \pm \\
1.70\end{array}$ & $130.89 \pm 1.940$ \\
\hline
\end{tabular}

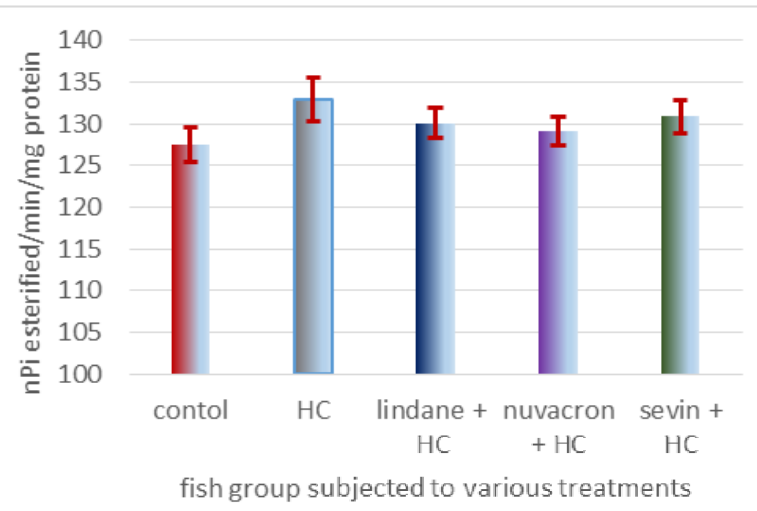

Figure 4: $\mathrm{Na}^{+} \mathrm{K}^{+}$ATPase activity in the gill of Oreochromis mossambicus treated with $\mathrm{HC}$ and exposed to pesticides

\section{Discussion}

Indiscriminate use of pesticides contaminates the natural piscine habitat. Pesticide residues reach the piscine body through branchial and oral surface and this change the ionic composition of body fluids. This induces stress in fish by altering both its internal and external milieu. As a result the activity of the osmotic organs such as gills show marked variation in their function, which is reflected in stimulated rate of activity of branchial osmoregulatory enzymes. Osmotic gradient between body and environmental fluid is mainly balanced by $\mathrm{Na}^{+} \mathrm{K}^{+} \mathrm{ATPase}$ enzymatic pump located in the key osmoregulatory tissues like the intestinal mucosa and gill epithelium [3], [7], [16], [19]. ATPase require $\mathrm{Na}^{+}$ $\mathrm{K}^{+} \mathrm{Mg}^{2+}$ and $\mathrm{Ca}^{2+}$ ions for their activity and are involved in the cleavage of ATP to ADP/ AMP and inorganic phosphate with the liberation of energy [10]. ATPase could be used as an indicator of Physiological changes [17]. The present study indicates that the hormone cortisol modulates the activity of membrane protein $\mathrm{Na}^{+} \mathrm{K}^{+}$ATPase in the gills. $\mathrm{Na}^{+} \mathrm{K}^{+}$ATPase activity is associated with cellular $\mathrm{Na}$ turnover and is increased in teleost gills when treated with cortisol. This enzyme can be taken as meaningful index of cellular activity and represents a useful toxicology tool since the toxic effect of various modulators on $\mathrm{Na}^{+} \mathrm{K}^{+}$ATPase activity has been elucidated [6], [31].

The active absorption and extrusion of ions across the gills is related to the presence of $\mathrm{Na}^{+} \mathrm{K}^{+}$ATPase. Maintenance of adequeate $\mathrm{Na}^{+} \mathrm{K}^{+}$ATPase in the gills depends on the action of cortisol [8], [12], [23]. Administration of cortisol could augment the decline of the plasma $\mathrm{Na}$ in the adrenalectomised fish [2],[5]. The stress release of cortisol increases the gill $\mathrm{Na}^{+} \mathrm{K}^{+}$ATPase activity In A. rostrate and A. japonica [15], [18]. Cortisol may function in both high and low salinities. Growth hormones and insulin like growth factor appear to act synergistically to affect ion regulation in sea water fishes stimulating both Na- K- activated ATP ase and Na-K-2Cl- cotransporter activity and chloride cell size, independent of their effects on growth [3], [26].

From the reports available from the other piscine species and the present findings, following conclusions can be drawn. Both pesticides and hormone cortisol affect osmoregulation in Oreochromis mossambicus. Pesticides increase the activity of osmoregulatory enzyme $\mathrm{Na}^{+} \mathrm{K}^{+}$ATPase drastically. Whereas the osmoregulatory hormone, hydrocortisone nullifies the effect of pesticides. Cortisol modulates the activity of membrane protein $\mathrm{Na}^{+} \mathrm{K}^{+}$ATPase in the gills.

Pesticides polluting our water resources endanger the wonder-provoking biodiversity. This paper invites the attention of the public and the authorities to expedite immediately legislative measures and effect public conscientisation against the indiscriminate use of pesticides.

\section{References}

[1] A. J. Mttay, Fish endocrinology, Croom Helm, London and Sydney,1985.

[2] D.G. Butler,W.C. Clarke, E.M. Donaldson and R.W. Langford, "Surgical adrenalectomy of a teleost fish, Anguilla anguilla, effect of plasma cortisol and tissue electrolyte and carbohydrate concentration," General comparative Endocrinology, (12), pp. 503-514, 1969.

[3] D.H. Evans, "Cell signaling and ion transport across the fish gill epithelium," Journal of experimental Zoology, 293, pp. 336-347, 2002.

[4] D.H. Evans, P.M. Piermarini and W.T.W. Potts, "Ionic transport in the fish gill epithelium," Journal of Experimental Zoology, (283), pp. 641-652, 1999.

[5] D.K.O. Chan, I. Chester Jones, I.W. Henderson and J.C. Rankin, "Studies on the experimental alteration of water and electrolyte composition of eel Anguilla anguilla," Journal of Endocrinology, 37(2), pp. 297-317,1967.

[6] E. Cotou, I. Castritsi- Catharios and Moraitou Apostolopoulou, " Surfactant based oil dispersant toxicity to developing nauplii of artemia: effects on ATPase enzymatic system," Chemosphere, (42), pp. 959-964, 2001.

[7] F.H. Epstein, A.I. Katz and G. E. Pickford, "Sodium and Pottassium activated adenosine tri phosphatase of gills : role in adaptation of teleosts to salt water," Science, 156, pp.1245-1247, 1967.

[8] F.H. Epstein, M. Cynaman and W. Mc. Kay, "Endocrine control of $\mathrm{Na}^{+} \mathrm{K}^{+}$ATPase and sea water adaptation in Anguilla rostra, General Comparative Endocrinology, (16), pp. 323-328, 1971.

[9] F. L. Mayer, D.J. Versteeg, M.J. Mekee, L.C. Folmar, R.C. Graney, D.C. Mccume and B.A. Rattner, " Physiological and non- specific biomarkers," in Physiological and Histological Markers of Anthropogenic Stress, R.J. Huggett, R.A. Kimerle, Jr. P.M. Mehrle and H.L. Bergman (eds),Lewis Publishers, Boca Raton USA, 1992.

[10] G. Begum, "Organ specific ATPase and phosphorylase enzyme activities in a food fish exposed to carbamate insecticide and recovery response," Fish Physiology and biochemistry, 37 (1), pp. 61-69, 2011.

[11] G. De Renzis and M. Barnancin, " Ion transport and gill ATPase," in Fish Physiology, W. S. Hoar and D. J. Randall (eds), Academic Press, New York, 1984.

\section{Volume 5 Issue 2 February 2016}




\section{International Journal of Science and Research (IJSR) \\ ISSN (Online): 2319-7064}

Index Copernicus Value (2013): 6.14 | Impact Factor (2014): 5.611

[12] G.E. Pickford, P.K.T. Pang, E Weinstein, J. Torretti, E. Handler and F.H. Epstein, " The response of the hypophysectomised cyprinodont, Fundulus heteroclistus, to replacement therapy with cortisol, effects on blood serum and sodium potassium activated adenosine triphosphate in the gills, kidney and intestinal mucosa," General Comparative Endocrinology, 14, pp. 524-534, 1970.

[13] G. E Pickford, R.W. Griffith, J. Torretti, E. Hendlez and F. H. Epstein, "Branchial reduction and renal stimulation of $\mathrm{Na}^{+} \mathrm{K}^{+}$ATPase by prolactin in hypophysectomized killifish in fresh water", Nature (228), pp. 378-379, 1970.

[14] I. W. Henderson and I. Chester Jones, " Endocrine influence on the net renal fluxes of sodium and potassium in European eel Anguilla anguilla," Journal of Endocrinology, 37, pp. 319-325, 1967.

[15] J.N. Forrest, A.D. Coben, D.A. Schon and F.H. Epstein, “ $\mathrm{Na}$ transport and $\mathrm{Na}^{+} \mathrm{K}^{+}$ATPase in gills during adaptation to sea water, effect of cortisol," American Journal of Physiology, 224, pp. 709-717, 1973.

[16] J.N. Foskett, H.A. Burn, T.E. Machen and M.Corner, "Chloride cells and the hormonal control of teleost fish osmoregulation," Journal of experimental biology, 106, pp.255-281, 1983.

[17] K. Hay and B.A. Waiwood, "Adenylate energy charge and ATPase activity : potential biochemical indicators of sub lethal effects caused by pollutants in aquatic animals," in Aquatic Toxicology, N.J.Wiley (eds), Jo and Sons, New York, USA, 1983.

[18] M. David, J. Sangeetha, E.R. Harish, J. Shrinivas and V.R. Naik, " Deltamethrin induced alteration in $\mathrm{Na}^{+}-\mathrm{K}^{+}, \mathrm{Mg}^{2+}$, $\mathrm{Ca}^{2+}$ associated ATPase activity in the fresh water fish Cirrhnus mrigala," International Journal of Pure and applied Zoology, II(2), pp. 175-181,2014.

[19] M. Kamiya, “ Na-K- activated adenosine triphosphatase in isolated chloride cells from eel gills," Comparative Biochemistry Physiology, 13. Pp. 611-617, 1972.

[20] N.L. Collie and T. Hirano, "Mechanisms of hormone actions on intestinal transport," in Vertebrate endocrinology : Fundamentals and Biomedical Implications, Academic press New York, 1987.

[21] N. Mayer, J. Matez, D.K.O. Chan, M. Foster and I. Jones Chester, "Cortisol, a sodium excreting factor in eel, Anguilla anguilla adapted to sea water," Nature, 214, pp. 1118-1120, 1967

[22] N. Narendra Singh, D. Vijaik and A.K. Srivastava, "Insecticides and ionic regulation in teleosts: a review," Zoologica Poloniae, 47, pp. 3-7, 21-36, 2002.

[23] O.H. Lowery, N.V. Rosebrough, A. L. Farr and R.J. Randal, "Protein measurement with the Folin Phenol reagent," Journal of Biology and Chemisrty, 193, pp. 265275, 1951.

[24] R.M. Pelis and S.D. Mc Comic, "Effects of growth hormone and cortisol on $\mathrm{Na}^{+} \mathrm{K}^{+}-2 \mathrm{Cl}^{-}$cotransporter localization and abundance in the gills of Atlantic salmon," General and comparative endocrinology, 124, pp. 134-143, 2001.

[25] S.D. Mc Cormick, "Endocrine control of osmoregulation in teleost fish," American Zoology, 41, pp.781-794, 2002.

[26] S.D. McCormick, "Hormonal control of gill $\mathrm{Na}^{+} \mathrm{K}^{+}$ATPase and chloride cell function," in Cellular and Molecular approaches to fish ionic regulation, C.M. Wood, T.J. Shuttlework (eds), Academic press Sandiego, 1995.

[27] S.D. McCormick, "Cortisol directly stimulates differentiation of chloride cells in tilapia opercular membrane," American Journal of Physiology, 259, pp. 857 863, 1990.

[28] S. Krishnaveni, A. Chezhian, M. Ramesh and R. Manavalaramanujam, " Branchial and plasma $\mathrm{Na}^{+} \mathrm{K}^{+}$ ATPase- activity in fresh water teleost Cyprinus carpio var communis under methomyl toxicity," Indian Journal of Fisheries, 45 (2), pp. 197-200, 1998.

[29] S.L. Bonting, "Sodium - potassium actvated adenosine triphosphatease and cation transport", in Membranes and Ion Transport, Bittae, E.E. (eds), Wiley Interscience, London, 1970.

[30] S.S. Madsen, M.K. Jensen, J. Nohr and K. Kristiansen, "Expression of $\mathrm{Na}^{+} \mathrm{K}^{+}$ATPase in the brown trout, Salmo trutta: in vivo modulation by hormones and sea water," American Journal of Physiology Regular integrated comparative physiology, 269, pp. 1339-1345, 1995.

[31] V. Vesna, M. Tajana, P. Marijiana and K. Danjela, “ $\mathrm{Na}^{+} \mathrm{K}$ ATPase as the target enzyme for organic and inorganic compounds," Sensors, (8), pp.8321-8360, 2008.

[32] W.S. Marshall and S.E. Baryson, "Transport mechanism of sea water teleost chloride cells: an Inclusive model of multi-functional cell," Journal of Comparative Biochemistry and Physiology, 119A, pp. 97-106, 1998.

\section{Author Profile}

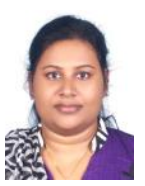

Jensy Roshan F. received the B. Sc. and M.Sc. degrees in Zoology from University of Kerala (Fatima Matha National College) in 2002 and 2005, respectively. Secured $1^{\text {st }}$ Rank in postgraduate degree. Qualified NET in 2009. Working as Assistant Professor (Zoology) in St. Johns College, Anchal, Kollam, Kerala, India (2011-till date). At present persuing research leading to $\mathrm{PhD}$. Published an article titled "The Ethics of Ecology" in the book, " Understanding the Environmental History of India" with ISBN 978- 81-924182-0-9 Published an article titled "Dose Dependent Effect of Acorus calamus on the Growth performance of Danio rerio" in the "Journal of Basic and Applied Biology", with ISSN 0973-8207. Research Papers Presented: 6 research papers in National seminars, 1 research paper in an International Conference, 1 research paper in an International Seminar. Has attended various workshops.

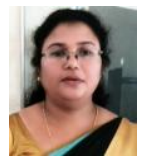

Dr. Anila George received the B. Sc. In Zoology and M.Sc. in Environmental Science from University of Kerala (St. Johns College) in 2002 and 2004, respectively. Received M.Phil. and Ph.D. from University of Kerala in 2007 and 2010. Working as Assistant Professor (Environmental Science) in St. Johns College, Anchal, Kollam, Kerala, India (2012-till date). Published an article titled "Potential impacts of climate change on ground water resources of Kerala"2012. Understanding the environmental history of India: Published by SN College Chempazhanthy,Thiruvananthapuram. ISBN:978-81-924182-0-99. Papers in Journals : 6, Papers published and presented in Conference proceedings : 7, Seminars \& Workshops : 14 